\title{
Orality, Literacy and Translation
}

\author{
Panchanan Mohanty \\ GLA University, Mathura \\ E-mail:panchananmohanty@gmail.com
}

\begin{abstract}
Though translation activities are more than two millennia old, the most significant activities in this field took place in the $20^{\text {th }}$ century. To be specific, contradictory theoretical positions were taken and entirely new kinds of questions were asked in the second half of this century. Scholars like Susan Bassnett (1998) even claimed that a translation should be treated as an independent and original text. But a number of writers, translators and scholars hold an opposite view. If we consider the translation activities of the ancient western civilizations of the world, we notice that those were mostly commissioned and literal in nature. Contrary to it, the situation in India was different. Though Valmiki and Vyasa composed the Ramayana and the Mahabharata respectively for the first time in Sanskrit, the Ramayanas and Mahabharatas written later in various vernacular languages of India are adaptations or transcreations. A careful analysis of the European, Arabic, and Chinese traditions show that those were literate in comparison with the vernacular Indian tradition that was predominantly oral. This orality gave a lot of freedom to the writers in the vernacular languages in ancient India to be creative and compose new texts. Therefore, orality was the driving force for this creativity and some western scholars' proposal that a translated text is an original text in not a new concept.

The other point I would like to make is that contrary to the popular belief, a literal translation of a literary text is also appreciated more (Newmark 1988:70-71). This position is validated in two of our case studies, i.e. Mohanty et al. (2008) and Mohanty and Sarath Chandra (2014). Therefore, I want to argue that 'free' translation was the mainstream in the climate of orality and not in literacy. This free trend endorsed by those scholars who treat translations as original texts is peripheral in the contemporary literate societies in which translations are usually commissioned. I will also argue that the differences between the free and the literal trends in translation are primarily due to the oral and the literate traditions that prevailed in India and in the other parts of the world mentioned above in the olden days.
\end{abstract}

In his "Introduction" to The Translation Studies Reader, Venuti (2000:1) states: "This Reader is intended to be an introduction to the field recognizable to the scholars who work within it. But the intention is also to challenge any disciplinary complacency, to produce a consolidation that is interrogative, to show what translation studies have been and to suggest what they might be." This statement clearly shows the fluidity and openness the field of translation studies has. Though this field is more than two thousand years old, there was an unprecedented spurt of research activities involving both theory and practice in the $20^{\text {th }}$ century. Benjamin (1923:16), one of the earliest theoreticians of this century, asserted: "If translation is a mode, translatability must be an essential feature of certain works." But the concept of translatability is neither well defined nor universally accepted. Benjamin (Ibid. 19) further states: "Unlike the words of the original, it (the nucleus) is not translatable, because the relationship between content and language is quite different in the original and the translation. While content and language form a certain unity in the original, like a fruit and its skin, the language of the translation envelops its content like a royal robe with ample

(c) AesthetixMS 2021. This Open Access article is published under a Creative Commons Attribution Non-Commercial 4.0 International License (http://creativecommons.org/licenses/by-nc/4.o/), which permits non-commercial re-use, distribution, and reproduction in any medium, provided the original work is properly cited. For citation use the DOI. For commercial re-use, please contact editor@rupkatha.com. 
folds." Then, by translating and retranslating into some 25 languages, Osgood (1971) has shown that "culture fair" nouns like house, fire, stone are easy to translate. Problems crop up when the social distance between the source language (SL) and the target language (TL) is large. An increase of this distance is concomitant with the increase of 'psychic noise', and that is why in such cases we notice a tendency to naturalize the SLT by making it 'decentered', which, according to Werner and Campbell (1970), means change of SL material so that it sounds smooth and natural in the TL. What it implies is that when the culture of the source language text (SLT) is different from that of the target language text (TLT), the translation is likely to be free. We find a lot of such examples in almost all major Indian languages during the renaissance period. The narrative poems Radhanath Ray (1848-19o8), the master craftsman and father of modern Oriya poetry, i.e. Kedara-Gauri (1886), Chandrabhaga (1886), and Usha (I888), etc. are based on Ovid's Pyramus and Thisbe, Daphne and Adonis, and Atlanta's Race respectively. But he never stated that these were translations. Nilakantha Das, the most influential scholar of Odisha in the 2oth century, discovered these and then only people came to know the sources of Ray's poetry. Regarding Ray's mesmerizing effect, Das (1991:316) has stated: "In fact, all his stories have been so indigenously located in the background of Orissa that an Oriya reader would accept them as parts of the legend and mythology of his region." At the same time, it should be emphasized that this need not be the case in a multilingual society sharing the same culture. The Indian culture was mostly oral. For this reason, even the Vedas were called 'shruti' as these texts were transmitted from one generation to the other orally. Most of the Ramayanas and Mahabharatas found in different Indian languages were also originally oral, and that is the reason for which there are so many versions of each text in almost all our languages. I am trying to emphasize here is that creation of a text in an oral culture will have thematic and structural variations due to its oral nature. But it does not normally happen in a literate culture like the Western one.

Regarding the success of a translation, Venuti's (1992: 4) opinion is: "A translated text is judged successful - by most editors, publishers, reviewers, readers, by translators themselves - when it reads fluently, when it gives the appearance that it is not translated, that it is the original, transparently reflecting the foreign author's personality or intention or the essential meaning of the foreign text." Notice that here the criteria of fluency and transparency are considered essential for the success of a translation, and Venuti calls it fluent translation strategy, which "...aims to efface the translator's crucial intervention in the foreign text: he or she actively rewrites in a different language to circulate in a different culture, but this very process results in a self-annihilation, ultimately contributing to the cultural marginality and economic exploitation which translators suffer today. At the same time, a fluent strategy effaces the linguistic and cultural difference of the foreign text: this gets rewritten in the transparent discourse dominating the target language culture and is inevitably coded with other target-language values, beliefs, and social representations, implicating the translation in ideologies that figure social differences and may well arrange them in hierarchical relations (according to class, gender, sexual orientation, race, nation). In this rewriting, a fluent strategy performs a labor of acculturation which domesticates the foreign text, making it intelligible and even familiar to the target-language reader, providing him or her with the narcissistic experience of recognizing his or her own culture in a cultural other, enacting an imperialism that extends the dominion of transparency with ideological discourses over a different culture." (Venuti 1992:4-5) Though Venuti's above mentioned position on 'translator's selfannihilation' is debatable, his emphasis on the reader is note-worthy. In fact, it is the reader who directly or indirectly controls both the process and the product of translation because it is meant for him/her. It is clearly reflected in the widely held view that the translated text should have a 
similar effect on the TL readers as the SLT had on the SL readers. But ironically, the reader had no role in the theorization of the translation until the second half of the 20 th century.

In fact, it was Itamar Even-Zohar, who set the new agenda of translation studies in the 1970s and set the ball rolling through his famous polysystem theoretical approach to translation by including translation as a part of the literary polysystem in his seminal publication Papers in Historical Poetics (1978). Besides providing a freshly different theoretical framework for a systematic analysis of literary translations, he is the first to draw our attention to the fact that translated literature plays a significant role in the evolution of TL culture. His contention is that intensive translation activities take place under the following three conditions:

(i) in the initial phase of the development of a literature

(ii) if a literature considers itself weak and/or marginalized

(iii) at the time of turning points or vacuums in the life of a literature

With all these, the binary distinction between the 'original' and the 'translation' became blurred, and all sorts of questions that were not conceivable earlier began to be asked. It will not be out of place to mention here that there was no such distinction made in India until the Renaissance in the 19th century. The absence of a widely accepted term for 'translation' in the Sanskrit language makes it clear that it was not an accepted or important intellectual activity in those days in India. In the absence of another accepted Indian language term, 'transcreation' of the earlier literary texts was the norm. I do not call this activity 'translation'. Paradigmatically, a translation is related to a single source text whereas a transcreation is related to multiple source texts. Therefore, we come across a number of Mahabharatas and Ramayanas in almost every Indian language. I should stress that due to this kind of mentality even today there has hardly been any effort to bring out dictionaries between any two Indian languages. I have discounted Hindi and English from this list as these are the official languages of the country. I want to argue here that if a language does not have bilingual dictionaries, translation activities are not likely to happen in it. So the hypothesis can be: "No bilingual dictionary, no translation activity." When we have grammars from the beginning, why not dictionaries? In fact, the concept of translation, as we understand it today, was imported from the West during the 19th century. In his review of History of Translation in India (Khan 2017), Trivedi (2018:5) also expresses the same view: “... for the past fifteen years or more, I have been going around the world proudly proclaiming that there was no translation in India before the British came..." Further, the concept of fidelity or faithfulness in translation was introduced and strengthened through close translations of the Bible and other religious texts to different Indian languages including some tribal languages, e.g. the first Bible in the Kui language appeared in Odia script in 1850 .

While commenting on Walter Benjamin's essay "The task of the translator" (1923), which calls translation 'afterlife' of an SLT, poststructuralist thinkers like Jacque Derrida valorize the translated text by stating that "The translation will truly be a moment in the growth of the original, which will complete itself in enlarging itself... And if the original calls for a complement, it is because at the origin it was not there without fault, full, complete, total, identical to itself." (quoted in Venuti 1992:7) This is how the originality of the SLT is replaced by intertextuality between SLT and TLT in the poststructuralist discourse. Immediately after this, translation has been a favourite hunting ground for literary scholars with different ideologies. Again, on the basis of support from the writings of Foucault, Derrida, and Barthes, etc., scholars have claimed translations as independent/original texts. Their argument is that readers of the time have no access to the original and hence the translation becomes the original for them. Of course, scholars like Pym (1995) have 
raised doubts if deconstruction can be a general theory of translation. However, we can ask a pertinent question here: Can such a major theoretical decision be taken solely with reference to the readers? What about the different types of readers? What about the original author, the translator, the translation critic? What about the intellectual property rights? Can a translator publish a translation without mentioning the source language author's name? The answer is certainly in the negative.

With reference to translation, Lefevere's (1992: 2) view is: "Translation is not just 'a window opened to another world', or some such pious platitude. Rather, translation is a channel opened, often not without a certain reluctance, through which foreign influences penetrate the native culture, challenge it and even contribute to subverting it." I want to point out here that Lefevere has preferred to use translation again in the second sentence instead of the pronoun 'it', and he does not like translation to be a 'pious platitude'. Bassnett (1993:151) has been more vocal about it when she states: "Translation is therefore a particularly special activity, since it enables a text to continue life in another context, and the translated text becomes an original text to continue life in another context, and the translated text becomes original by virtue of its continued existence in that new context." and "Writing does not happen in a vacuum, it happens in a context and the process of translating texts from one cultural system into another is not a neutral, innocent, transparent activity. Translation is instead a highly charged, transgressive activity, and the politics of translation and translating deserve much greater attention than has been paid in the past." (Ibid.16o-161) Dingwaney and Maier (1995) see translation as an act of violence (quoted in Bassnett and Trivedi 1999:5) In other words, these scholars are more interested in the cultural aspects as well as politics of literary translation rather than translation in its totality. A number of such scholars always consider translation in combination with the discipline of comparative literature. Needless to say that culture analysis is the life-line of comparative literature. It has been clearly voiced by Bassnett and Lefevere (1990:12): "Translation has been a major shaping force in the development of world culture and no study of comparative literature can take place without regard to translation."

There are problems that need to be mentioned here. First, these statements and positions like translation is a 'highly charged, transgressive activity' and an 'act of violence' are prescriptive in nature when the contemporary temper is to go for a descriptive or bottom-up approach. Then, the above mentioned scholars use the term 'translation' with specific reference to literary translation; but the reality is that translation of non-literary texts outnumber and outweigh the translation of literary texts in today's world. It can be seen on the medicine wrappers, hotel menu cards, user manuals of various gadgets, etc.

Let us now see how the descriptive data gives a different picture altogether. It is taken for granted that liberty is natural in translating poetry. But I want to argue that it need not be true. While comparing the two German translations of Baudelaire's Recueillement by Walter Benjamin and Stefan George, Newmark (1988:70-71) convincingly argues that the latter has rightly been considered a better translator because he is closer to the original, not because he is free. He (Ibid.71) states: "Both lexically and grammatically, George's openings are nearer to Baudelaire than Benjamin's. ...The word- and clause-order correspondence in George and Baudelaire is striking." He (Ibid.76) recommends that serious imaginative literature should be translated literally: "Literal translation is the first step in translation, and a good translator abandons a literal translation only when it is plainly inexact ... or badly written. A bad translator will always do his best to avoid translation word for word." Then, having analyzed a number of translations from other languages into English, Duff (1988:126) states: “...the thought and care invested by the translator should be directly proportional to the thought and care invested by the writer. The Translator must think 
with the writer, but he cannot do this thinking for him." Eco (2004:62) holds a similar view: "In very simple terms a translation should convey the same things and events as the original." Vinay and Darbelnet (1995) emphasize: "Literalness should only be sacrificed because of structural and metalinguistic requirements and only after checking that the meaning is fully preserved." There are many others who express the same opinion, e.g. Cohn (1961), Nobokov (2000), Steiner (2000), etc.

The third example deals with the relationship between law and language. In a fascinating study, Berg-Seligson (1998) demonstrates that the English translators interpreters of the monolingual Hispanic witnesses, who have a right to depose in Spanish in order to communicate effectively with their attorney in the United States court houses, can make or mar the case by the use of the English vocabulary chosen for this purpose. Though the Spanish-speaking witness's testimony is in the 'casual' and/or 'consultative' styles, some court interpreters render it in the 'hyperformal' style that avoid non-standard grammatical forms and vocabulary, used full syntactic forms without deleting the redundant parts and does not contract the be-verb as well as not. What is noteworthy is that this difference in the use of register presents the witnesses as "- more competent, more intelligent, and more trustworthy than he does when his testimony is rendered in English in a less formal style." (Ibid.605), and, as a result, the judgement is influenced. Similarly, Wodak-Engel (1984:97) has reported that “... (working class) defendants not socialized in these norms of language use are discriminated against, and only MC (middle class) defendants succeed, as a rule, in good image management before the judge."

It will not be out of place to mention that the French humanist Etienne Dolet (1509-1546), one of the earliest scholars to theorize translation, was "...tried and executed for heresy after 'mistranslating' one of Plato's dialogues in such a way as to imply disbelief in immorality." (BassnettMaGuire 1980:54) These examples make it evident that any bilingual person cannot become a translator. Then, like the other fields, training is necessary for translators, and a translation should be as close as possible to the original.

If we consider the translation activities of the ancient civilizations of the world, we notice that those were mostly commissioned and literal in nature. It is interesting to note at this point that those civilizations were also literate. With reference to the middle age of Latin, Kelly (2009:480) states: "Literary translation with its rhetorical, poetic imperatives had disappeared, and translation was now in the hands of philosophers and theologians. And as scientific language lends naturally to Platonist ideals, the goal soon became truth in Seneca's sense: conformity between language, concept and thing. Literal translation was generally seen as the way to truth, though there were a few protests from those trained in ancient rhetoric,...". On the other hand, the ancient Greeks were never interested in translation. "The first references to translation in the Greek context come from the early Byzantine period and concern the translation of legal texts." (Connolly and Bacopoulou-Halls 2009:419) A similar trend can be noticed in the Arabic and Chinese traditions. Regarding the Arabic tradition, Baker and Hanna's (2009:330) view is as follows: "With the introduction of paper, the process of transforming the oral Arabic culture into a literate one could proceed in earnest, with translation playing the main role in enabling this process to take shape." The manuscripts which were translated dealt with the subjects like "... mathematics, astronomy, philosophy, logic, medicine, chemistry, politics, etc. Literature was of relatively less interest during this period..." (ibid.) In ancient China, the equivalent term for translation was "...yiguan or yishi, literally 'translation official'. During the Tang Dynasty (618-906), a period in which cultural exchanges between China and her neighboring states reached a new height, a considerable number of foreigners who lived in China were employed as government interpreters and were allowed to accompany Chinese officials on diplomatic missions." (Hung and Pollard 2009:370) All these make 
it evident that the trend of translations in the European, Arabic, and Chinese traditions was literal and faithful to a large extent in the ancient period.

But the situation in India was entirely different. Though translations from Sanskrit, Pali and Prakrit to some other Asian languages took place in the olden days, those were mainly confined to the religious domain and to be specific Buddhism. There were no equivalents of 'translation' in them. Terms like tika, vyakhya, bhashya, varttika were used which primarily referred to interpretation. The Sanskrit term anuvada which is very frequently used for 'translation' at present in most literary Indian languages originally meant 'saying after or repetition' and its use as an equivalent of 'translation' is very recent. Though Valmiki and Vyasa composed the Ramayana and the Mahabharata respectively in Sanskrit, the vernacular Ramayanas and Mahabharatas are adaptations or transcreations. The treatment of themes and portrayal of characters in these vernacular texts are significantly different from the original Sanskrit texts. This was possible just because our cultures were predominantly oral. Though in the academic circles literacy practices are promoted against orality, the latter has a number of strong points, and creativity is the most significant among these. In fact, in the present day Indian context where literacy does not even mean functional literacy, our age-old orality needs to be foregrounded. It is well known that most of the modern Indian literatures have begun with the Ramayana or the Mahabharata stories. Not only that, the language of these compositions was the spoken variety of the period and the metres belonged to the folk domain. The point I want to underline here is that the contemporary western scholars' claim that a translated text is an original text is not really new. It was in practice in India earlier and it was possible just because our culture was predominantly oral. Of course, I will not call this activity translation for the reasons discussed below.

I want to argue that the European, Arabic, and Chinese traditions were literate whereas the vernacular Indian tradition was predominantly oral. This orality gave a lot of freedom to the writers in the vernacular languages in ancient India to create entirely new texts. This trend continued till the early 2oth century. But after consolidating on the Indian soil in India in the 18th and 19th centuries, the British and other European missionaries started translating the Bible and some religious texts into various Indian languages to preach Christianity. These translations were obviously literal and this is when translation was practised on a large scale and took roots on the Indian soil.

But the tradition of adaptation continued till the late $20^{\text {th }}$ century. I should cite an interesting and unique example from Odia. Guru Prasad Mohanty's Sahitya Akademi award winning poetry collection Samudra-snana opens with a long poem captioned Kalapurusa. In an interview, he has stated that he kept T. S. Eliot's The Waste Land open on his table and wrote Kalapurusa. But in spite of the similarities between both the texts, Odia scholars and critics have not called Kalapurusa a translation of The Waste Land. We must remember that Guru Prasad Mohanty received the Akademi award in 1973 for his original work in the Odia language.

Actually, the translations of the Bible and other religious literature by the missionaries into Indian languages had an enormous impact on the development of prose in these languages. In other words, not only certain English sentence structures were incorporated into Indian languages, but also the punctuation system was entirely borrowed. Taking such facts into consideration, Duff (1984) has used 'third language' for translation.

Let us now consider the views of some original authors and translators on this subject. Sitakant Mahapatra, one of the most widely translated contemporary Indian writers and a Jnanpith awardee Oriya poet, states: "Some of my work was translated directly from Oriya to foreign languages. Others were translated into English. I have my reservations about such re translations. 
But my consolation is that the translators are major poets themselves. I got the feeling from some reviews that these translations were done with sensitivity and love for the original milieu and context." (Mahapatra 2005:3) Then, Giovanni Pontiero, one of the most celebrated Latin-American translators, has clearly stated: "I never take liberties with a text at the outset, because a translator's main concern is, like the author's himself, with words. In one sense, a translator's task is even more difficult than that of the writer, for he must subordinate himself to two languages, not one. But how can I then move from faithful rendering to a creative interpretation of the source text? Here my approach is to be as literal as possible in the first instance, to capture as much of the author's idiosyncrasies as are transferable into the target language, and only at the first revision, to make the adjustments required by the demands of the target language." (Pontiero 1997:22-23)

The Czech Nobel laureate Milan Kundera is famous for his strict views about the translators of his writings. He even questions the idea of translation in his Book of Laughter and Forgetting as follows: "Litost is an untranslatable Czech word. Its first syllable, which is long and stressed, sounds like the wail of an abandoned dog. As for the meaning of the word, I have looked in vain in other languages for an equivalent, though I find it difficult to imagine how anyone can understand the human soul without it." (Quoted in Kelly and Zetzsche 2012:98). As this word is an aggregate of sympathy, grief, remorse, and longing, Kundera asked his translators not to translate and leave it like that.

We should also take note of Mahapatra's "reservations" about "re-translations" as these are twice-removed from the original, Pontiero's contention to try to be "as literal as possible," and Kundera's concern about his translations. This position is validated in two of our case studies. Mohanty et al. (2008) have examined the two English translations of Phakir ${ }^{2}$ Mohan Senapati's autobiography Atmajibanacharita by John Boulton (1985) and J. K. Nayak and Prodeepta Das (1997) and found that John Boulton's translation which was adjudged better and more readable by a group of readers was more literal than the other one. This position was further vindicated in Mohanty and Sarath Chandra's (2014) study of the two translations of Faiz Ahmed Faiz's poems by V. G. Kiernan (1971/2006) and Shiv K. Kumar (2005). Another important point to emphasize here is that in both the cases the translators who were adjudged better are native speakers of the target languages.

Keeping these in view and in order to avoid of the problems inherent in the literary, cultural and linguistic theories of translation, has not only coined a new term "Translation Studies", but also made the founding statement for this discipline in his seminal but not so-very-widely read paper titled "The name and nature of Translation Studies". A careful look at the literature on translation theory and a study of translation products reveals that entirely different methods are followed in translating the same text and, as a result, widely divergent views are expressed as to what translation theory should be like. His views do not conform to either the so-called theories of translation or to the sciences of translation. While rejecting the existing translation theories he states: "... there is much valuable study and research being done in the discipline, and a need for much more to be done, that does not strictly speaking, fall within the scope of theory formation". (Holmes, 1972:174) He also questions the position that translation is a science and argues: “... I question whether we can with any justification use a designation for the study of translating and translations that places it in the company of mathematics, physics, and chemistry, even biology, rather than that of sociology, history, and philosophy - or for that matter of literary studies." (Ibid.175)

After coining the new term 'Translation Studies', Holmes (1972) has made the founding statement by drawing an outline regarding the scope of the discipline: “... translation studies thus has two main objectives: (1) to describe the phenomena of translating and translation(s) as they manifest themselves in the world of our experience, and (2) to establish general principles by means 
of which these phenomena can be explained and predicted." (Ibid.176) His emphasis was on developing "... a full, inclusive theory accommodating so many elements that it can serve to explain and predict all phenomena falling within the terrain of translating and translation, to the exclusion of all phenomena falling outside it" because most of the translation theories developed till then were "... a little more than prolegomena to such a general translation theory." (Ibid.:178)

To sum up, I agree with George Steiner, an influential translation theorist, who believes that a theory of translation has to stand on a theory of language and states: "A study of translation is a study of language." (Steiner 1975: 47) Thus, it can be argued that construction of a theory of translation has to draw on a theory of language. I want to argue that 'free translation' was the mainstream in the climate of orality, and not in literacy. Therefore, some contemporary western scholars' assertion that a translation is an independent and original text is not really new and it does not occupy the central position in the present-day literate cultures in which translations are usually commissioned. My contention is that the differences between the free and literal trends are primarily due to the oral and literate traditions that prevailed in India and in the other parts of the world. If we accept a bottom-up approach in the field of translation studies, literal translation should be the touch-stone as proposed by some of the leading scholars of the world.

\section{Notes}

1. I am thankful to Dr. Kasturi Sinha Ray, Bakka Srishailam, and Divya Shikhar, Dept. of English, GLA University for their help in preparing this draft.

2. Though people write 'Fakir Mohan Senapati', Senapati himself spelt his first name 'Phakir', and that is why, the company he established was 'P.M. Senapati \& Co.'. I prefer the way he spelt his name.

\section{Bibliography}

Baker, Mona 1992. In Other Words: A Coursebook on Translation. London: Routledge.

Bassnett-McGuire, Susan 1980. Translation Studies. London: Methuen.

Bassnett-McGuire, Susan 1993. Comparative Literature: A Critical Introduction. Oxford: Blackwell Publishers.

Bassnett, Susan \& André Lefevere (eds.) 1990. Translation, History and Culture. London: Pinter.

Bell, Roger T 1991. Translation and Translating: Theory and Practice. London and New York: Longman.

Benjamin, Walter 1923/200o. The task of the translator. In: Venuti (ed.) 2000.

Berk-Seligson, Susan 1998. The role of register in the bilingual courtroom: evaluative reactions to interpreted testimony. In: Linguistics at Work: A Reader of Applications, ed. by Dallin D. Oaks. Fort Worth: Harcourt Brace College Publishers of Applications.

Boulton, John (1985) My Times and I. Bhubaneswar: Orissa Sahitya Academy.

Brislin, R.W. (ed.) 1976. Translation: Application and Research. New York: Gardner Press, Inc.

Catford, J.C. 1965. A Linguistic Theory of Translation: An Essay in Applied Linguistics. London: Oxford University Press.

Das, Sisir Kumar 1991. A History of Indian Literature (180o-1910), Western impact: Indian Response. New Delhi: Sahitya Akademi. 
Dingwaney, Anuradha and Carol Maier (eds.) 1995. Between Languages and Cultures: Translation and Crosscultural Texts. Pittsburgh and London: University of Pittsburgh Press.

Duff, Alan 1984. The Third Language: Recurrent Problems of Translation into English. Oxford: Pergamon Press. (revised edition, first printed in 1981)

Eco, Umberto 2004. Mouse or Rat? Translation as Negotiation. London: Phoenix.

Even-Zohar, Itamar 1978. Papers in Historical Poetics. Tel Aviv: The Porter Institute of Poetics and Semiotics.

Fawcett, Peter 1997. Translating and Language: Linguistic Theories Explained. Manchester: St Jerome Publishing.

Gentzler, Edwin 1993. Contemporary Translation Theories. London and New York: Routledge.

Holmes, James S. 1972/200o. The name and nature of translation studies. In: The Translation Studies Reader, ed. by Lawrence Venuti. London and New York: Routledge.

Hung, Eva and David Pollard 20o1. Chinese Tradition. In Routledge Encyclopedia of Translation Studies, ed. by Mona Baker. London and New York: Routledge.

Jakobson, Roman 196o. Closing statement: linguistics and poetics. In: Style in Language, ed. by T.A. Sebeok. Cambridge, Mass: MIT Press.

Khan, Tariq (ed.) 2017. History of Translation in India. Mysuru: National Translation Mission/ Central Institute of Indian Languages.

Lefevere, André 1978. Translation studies: the goal of the discipline. In: Literature and Translation, ed. by J. Holmes, J. Lambert and A. Lefevere. Leuven: ACCO.

Lefevere, André 1992. Translation/History/Culture: A Source Book. London: Routledge. Mahapatra, Sitakant 2005. Universal appeal. The Hindu Literary Review (January 1, 2006). p.3.

Mohanty, Panchanan, Vaishnavi Ramaswamy, and Ramesh C. Malik 2008. Translations of Phakir Mohan Senapati's autobiography: A review. Translation Today, Vol. 5, Nos. 1\&2, pp. 117-141.

Mohanty, Panchanan and P. Sarath Chandra 2014. Two English translations of Faiz Ahmed Faiz's poems: A comparative study and its implications, in Poetry of Protest: Internalizing Faiz Ahmed Faiz, ed. by Ali Refad Fatihi. Saarbrücken: Lambert Academic Publishing.

Nayak, Jatindra K. and Prodeepta Das (trans.) (1997). Story of My Life. Bhubaneswar: Sateertha. Newmark, Peter 1988. A Textbook of Translation. London: Prentice-Hall.

Nida, E.A. 1964. Toward a Science of Translating. Leiden: EJ Brill.

Nida, E.A. 1975. The Componential Analysis of Meaning. The Hague: Mouton.

Nord, Christiane. 1997. Translating as a Purposeful Activity: Functional Approaches Explained. Manchester: St. Jerome Publishing.

Novokov, Vladimir 200o. Problems of Translation: Onegin in English, in Venuti (ed.).

Pontiero, Giovanni 1997. The risks and rewards of literary translation. In: The Translator's Dialogue: Giovanni Pontiero, ed. by Pilar Orero and Juan e. Sager. Amsterdam / Philadelphia: John Benjamins Publishing Company..

Pound, Ezra 1918/2003. Guido's relations. In: Venuti (ed.) 2000.

Pym, Anthony 1995. Doubts about Deconstruction as a General theory of Translation. TradTerm 2, pp. 11-18.

Richards, I.A. 1953. Toward a theory of translating. In: Studies of Chinese Thought, ed. by Arthur F. Wright. Chicago: University of Chicago Press. 
Rose, Marilyn G 1982. Walter Benjamin as a translation theorist: a reconsideration. Dispositio VII, 19-20-21, pp.163-176.

Steiner, George 1975. After Babel: Aspects of Language and Translation. van Gorcum: Assen.

Steiner, Erich and Colin Yallop (eds.) 2001. Exploring Translation and Multilingual Text Production: Beyond Content. Berlin: Mouton de Gruyter.

Trivedi, Harish 2018. Translation in India: A Curious History. The Book Review, February.

Venuti, Lawrence (ed.) 1992. Rethinking Translation: Discourse, Subjectivity, Ideology.London and New York: Routledge.

Venuti, Lawrence (ed.) 2000. The Translation Studies Reader. London and New York: Routledge.

Vinay, J. -P and J. Darbelnet 1995. Comparative Stylistics of French and English: A Methodology for Translation. Amsterdam and Philadelphia, PA: John Benjamins.

Werner, O. and D. Campbell 1970. Translating, working through interpreters, and the problem of decentering. In: A Handbook of Method in Cultural Anthropology, ed. by R. Naroll and R. Cohen. New York: American Museum of Natural History.

Wilss, Wolfram 1982. The Science of Translation: Problems and Methods. Tübingen: Gunter Narr Verlag.

Wodak-Engel, Ruth 1984. Determination of guilt: Discourse in the Courtroom. In: Language and Power, ed. by Cheris Kramarac, Muriel Schulz, and William M. O'Barr. Beverly Hills, London, New Delhi: Sage Publications. 